\title{
Elevated Carbon Dioxide and Nitrogen Impact Wheat and Its Aphid Pest
}

\author{
Eva Carreras Navarro ${ }^{1,2}$, Shu Kee Lam² and Piotr Trębicki ${ }^{1,2 *}$ \\ ${ }^{1}$ Agriculture Victoria, Horsham, VIC, Australia, ${ }^{2}$ School of Agriculture and Food, Faculty of Veterinary and Agricultural \\ Sciences, The University of Melbourne, Parkville, VIC, Australia
}

OPEN ACCESS

Edited by:

Félix Ortego,

Consejo Superior de Investigaciones

Cientificas (CSIC), Spain

Reviewed by:

Bing Yang,

Chinese Academy of Sciences, China Vicente S. Marco-Mancebón, University of La Rioja, Spain

*Correspondence: Piotr Trębicki piotr.trebicki@agriculture.vic.gov.au; piotr.trebicki@unimelb.edu.au

Specialty section: This article was submitted to Plant Pathogen Interactions, a section of the journal

Frontiers in Plant Science

Received: 12 September 2020

Accepted: 10 November 2020

Published: 01 December 2020

Citation:

Carreras Navarro E, Lam SK and Trębicki P (2020) Elevated Carbon Dioxide and Nitrogen Impact Wheat and Its Aphid Pest.

Front. Plant Sci. 11:605337. doi: 10.3389/fpls.2020.605337
The rise in atmospheric carbon dioxide $\left(\mathrm{CO}_{2}\right)$ generally increases wheat biomass and grain yield but decreases its nutritional value. This, in turn, can alter the metabolic rates, development, and performance of insect pests feeding on the crop. However, it is unclear how elevated $\mathrm{CO}_{2}\left(\mathrm{eCO}_{2}\right)$ and nitrogen $(\mathrm{N})$ input affect insect pest biology through changes in wheat growth and tissue $\mathrm{N}$ content. We investigated the effect of three different $\mathrm{N}$ application rates (low, medium, and high) and two $\mathrm{CO}_{2}$ levels (ambient and elevated) on wheat growth and quality and the development and performance of the bird cherry-oat aphid, a major cereal pest worldwide, under controlled environmental conditions. We found that $\mathrm{eCO}_{2}$ significantly decreased total aphid fecundity and wheat $\mathrm{N}$ content by 22 and $39 \%$, respectively, when compared to ambient $\mathrm{CO}_{2}\left(\mathrm{aCO}_{2}\right)$. Greater $\mathrm{N}$ application significantly increased total aphid fecundity and plant $\mathrm{N}$ content but did not offset the effects of $\mathrm{eCO}_{2}$. Our findings provide important information on aphid threats under future $\mathrm{CO}_{2}$ conditions, as the heavy infestation of the bird cherry-oat aphid is detrimental to wheat grain yield and quality.

Keywords: climate change, food security, carbon dioxide, fertilizer, agriculture, wheat pest

\section{INTRODUCTION}

The current atmospheric carbon dioxide $\left(\mathrm{CO}_{2}\right)$ concentration of $414 \mathrm{ppm}$ (NOAA, 2020) is projected to double by the end of this century (RCP 8.5; Stocker et al., 2013), resulting from fossil fuel combustion and deforestation (IPCC, 2014). Climate models predict an increased occurrence of extreme temperature, rainfall, and drought events under future climatic conditions (IPCC, 2012), therefore, threatening the resilience of current food production systems (Campbell et al., 2016). Projections indicate that feeding a world population of 9.7 billion by 2050 (United Nations, 2019) will require doubling the current food production (Mbow and Rosenzweig, 2019). Thus, meeting the future food demand is considered a major challenge in the twentyfirst century (Mbow and Rosenzweig, 2019).

Wheat (Triticum aestivum L.) is one of the most important cereal crops produced and consumed worldwide. It is a main source of carbohydrate in North America, Australia, Europe, the Middle East, Asia, and North and Sub-Saharan Africa (Awika et al., 2011; Shewry and Hey, 2015), and provides approximately $20 \%$ of the protein in human diet (Wang et al., 2013). Wheat has shown to be highly responsive $\left(11.8-38 \%\right.$ biomass increase) to $\mathrm{CO}_{2}$ fertilization (Jablonski et al., 2002; Högy et al., 2009; O'Leary et al., 2015; Fitzgerald et al., 2016). However, elevated $\mathrm{CO}_{2}\left(\mathrm{eCO}_{2}\right)$ also decreases the protein content and nutritional quality of wheat-derived 
products through decrease in plant nitrogen $(\mathrm{N})$ content (Taub et al., 2008; Myers et al., 2014). A potential adaptation strategy to maintain the nutritional quality of wheat is optimizing the use of nitrogen fertilizer.

There are a number of biotic stresses behind crop losses worldwide, among which insect pests are of high importance. Despite the extensive use of insecticides, the total loss of food crops attributed to insect pests is estimated at $30-40 \%$ (GarcíaLara and Saldivar, 2016). In grain crops, such as rice, maize, and wheat, insect pests are currently responsible for $5-20 \%$ yield loss (Deutsch et al., 2018). Aphids are among the most important cereal pests worldwide, inflicting economic damage directly through feeding and through the spread of viruses. In temperate regions, the bird cherry-oat aphid, Rhopalosiphum padi, is one of the most important cereal pests (Morales-Hojas et al., 2020; Trębicki, 2020). It is distributed in all wheat growing regions worldwide and is the main vector of Barley yellow dwarf virus (BYDV), responsible for significant losses in cereal yield and quality (Smith and Sward, 1982; Jones and Naidu, 2019).

Climate change will impact aphid population size, migration activity, and distribution (Luck et al., 2011; Ryalls and Harrington, 2016; Trębicki et al., 2017; Deutsch et al., 2018; Trębicki and Finlay, 2019; Trębicki, 2020). In particular, $\mathrm{eCO}_{2}$ has shown to increase aphid metabolic rates and, thus, feeding behavior (Robinson et al., 2012; Trębicki et al., 2016), and to alter aphid development and fecundity through changes in host biochemistry (Johnson and Jones, 2017; Johnson and Züst, 2018; Trębicki and Finlay, 2019; Moreno-Delafuente et al., 2020). There are contrasting findings in terms of the effect of $\mathrm{eCO}_{2}$ on aphid fecundity (Xing et al., 2003; Robinson et al., 2012; Oehme et al., 2013; Ryan et al., 2014; Ryalls and Harrington, 2016; Trębicki et al., 2016; Moreno-Delafuente et al., 2020), as it can be highly species/host specific (Hughes and Bazzaz, 2001). In terms of aphid development time, the findings can vary; for example, $\mathrm{eCO}_{2}$ did not affect the development time of $R$. padi reared on wheat (Trębicki et al., 2016) but significantly increased that of Myzus persicae reared on bell pepper (Dáder et al., 2016).

Despite its positive impact on crop production, increased $\mathrm{N}$ inputs have shown to increase insect populations by improving the nutritional quality of host plants (Cisneros and Godfrey, 2001; Aqueel and Leather, 2011), thereby increasing the damage of insect pests. In a meta-analysis, higher $\mathrm{N}$ inputs improved the performance of herbivore insects reared on broadleaf plants and conifers (Li et al., 2016). Greater N fertilizer application rates significantly increased the fecundity and longevity of the aphid Hysteroneura setariae when reared on rice (Jahn et al., 2005), and the fecundity and intrinsic rate of increase (maximum growth rate per individual for a population) of the cereal aphid Metopolophium dirhodum when reared on wheat (Gash, 2012). Moreover, the addition of $\mathrm{N}$ fertilizer increased the fecundity and decreased the development time of the bird cherry-oat aphid and the English grain aphid (Khan and Port, 2008).

Research has shown that changing climate conditions, mainly driven by the increase in $\mathrm{CO}_{2}$, will continue to alter the productivity and suitability of farmland (Mbow and Rosenzweig, 2019). As previously mentioned, increasing $\mathrm{CO}_{2}$ has a positive effect on C3 crop growth through carbon fertilization (Mitchell et al., 1993;
Jablonski et al., 2002; Bloom et al., 2010; Taub, 2010; Lam et al., 2012; Ryan et al., 2014; O'Leary et al., 2015; Fitzgerald et al., 2016) but decreases the $\mathrm{N}$ content and nutritional quality (protein and macronutrients) of food crops (Taub et al., 2008; Myers et al., 2014; Vassiliadis et al., 2016). To replenish the extra $\mathrm{N}$ removed from grain cropping systems under $\mathrm{eCO}_{2}$ (Lam et al., 2012), increasing or optimizing $\mathrm{N}$ fertilizer application may be considered (Walker et al., 2017). The increase in $\mathrm{N}$ input, however, uncovers other challenges through its indirect impact on insect pests and diseases. Insect pests are known to display a strong response to plant $\mathrm{N}$ content (Cisneros and Godfrey, 2001; Khan and Port, 2008; Aqueel and Leather, 2011; Gash, 2012; Li et al., 2016). However, increased N fertilization and its indirect effect on insect-plant herbivore interactions under $\mathrm{eCO}_{2}$ are largely unknown (Sudderth et al., 2005; Ryan et al., 2014). Hence, this research investigates the interaction between current ambient and projected elevated $\mathrm{CO}_{2}$ levels $\left[\right.$ ambient $\mathrm{CO}_{2}$ $\left(\mathrm{aCO}_{2}\right)=400 \mathrm{ppm}$ and $\left.\mathrm{eCO}_{2}=800 \mathrm{ppm}\right]$ and three levels of $\mathrm{N}$ fertilization on wheat growth and quality, and on the development and performance of the bird cherry-oat aphid. We hypothesize that the effect of $\mathrm{eCO}_{2}$ on wheat growth and quality and consequently on aphid development and performance will be mitigated by greater $\mathrm{N}$ application rates.

\section{MATERIALS AND METHODS}

\section{Source of Bird Cherry-Oat Aphid}

A single adult female bird cherry-oat aphid obtained from a field located near the Grains Innovation Park facility in Horsham, VIC, Australia was placed on an individual potted wheat (cv. Mace) plant. After $24 \mathrm{~h}$, the female aphid and all its progeny except for a single nymph were removed. This nymph was placed on a new wheat plant in order to start a colony that was then used for the experiment. This clonal lineage was reared on wheat for over five generations prior to the experiment.

\section{Plant $\mathrm{CO}_{2}$ and Nitrogen Growing Conditions}

All plants were grown in $0.5 \mathrm{~L}$ pots filled with $300 \mathrm{~g}$ of potting mix. Trace elements (Manutec PTY LTD) and different amounts of ammonium sulfate (Richgro Garden Products), corresponding to the three $\mathrm{N}$ treatments, were added into the nutrient-free potting mix, and then thoroughly mixed in a cement-mixer. The amount of ammonium sulfate applied to each $\mathrm{N}$ treatment was calculated based on wheat rooting depth, potting mix bulk density, and concentration of $\mathrm{N}$ in ammonium sulfate (21\%; Speight, 2017). The low, medium, and high N treatments consisted of 141,282 , and $423 \mathrm{mg} / 100 \mathrm{~g}$ of ammonium sulfate, respectively.

Plants were grown in $\mathrm{CO}_{2}$-controlled plant growth chambers (Thermoline Scientific, TPG-1260) at a constant temperature of $20^{\circ} \mathrm{C}$, and 16:8 D:L photoperiod (light intensity: $1000 \mu \mathrm{mol} \mathrm{m}^{-2} \mathrm{~s}^{-1}$ at plant canopy level, powered by five high pressure sodium $400 \mathrm{~W}$ lights and five $77 \mathrm{~W}$ incandescent lights). Plant growth chambers were set at either $\mathrm{aCO}_{2}(400 \mathrm{ppm})$ or $\mathrm{eCO}_{2}(800 \mathrm{ppm})$. Of the 48 potted plants that were sown 
for each $\mathrm{N}$ treatment, 24 were placed in a tray and grown at one of the two $\mathrm{CO}_{2}$ conditions. The same amount of water was applied to each tray daily. $\mathrm{CO}_{2}$ concentration and wheat plants were alternated between the chambers twice a week to eliminate any chamber-induced effect.

\section{Plant $\mathrm{CO}_{2}$ and Nitrogen Response Assessment}

Plant growth parameters including plant height, tiller number, and chlorophyll content were measured on a weekly basis for 4 consecutive weeks. The change in plant height at different growth stages was used to evaluate plant growth (Demir et al., 2018), and the tiller number was used as an indirect measurement of biomass (Boe and Beck, 2008). Chlorophyll content was measured using SPAD chlorophyll meter (Soil Plant Analytical Development-502Plus, Konica Minolta, Japan), generally used as a proxy for foliar $\mathrm{N}$ content (Xiong et al., 2015). The SPAD measurement was taken from the first fully extended leaf of the main stem and was recorded as an average of three readings per plant. At the 4 th week of assessment, 10 wheat plants per $\mathrm{N}$ and $\mathrm{CO}_{2}$ treatment were destructively sampled; in addition to plant height, tiller number, and chlorophyll content, dry weight and $\mathrm{N}$ content were measured.

\section{Bird Cherry-Oat Aphid Development and Fecundity}

To evaluate aphid development and fecundity, a single adult bird cherry-oat aphid was placed on the second fully extended leaf of the main stem of each of the 14 replicates (insect-plant combination) for each treatment. Each aphid was confined in a clip cage (the top of the clip cage was covered with a fine mesh to allow transpiration) that was placed onto a transparent acrylic platform and secured to the plant by a hair clip (Figure 1; Trębicki et al., 2016). After $24 \mathrm{~h}$, the female aphid and all its progeny, except for one nymph, were removed. Each individual nymph was assessed daily until adulthood. During each assessment, and for each of the 14 replicates, the instar number was recorded

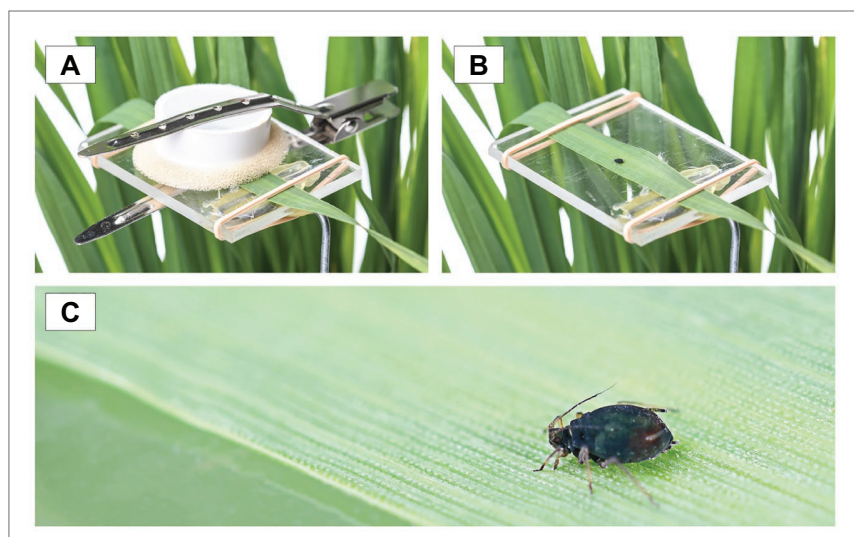

FIGURE 1 | (A) The bird cherry-oat aphid was confined in a clip cage to study its development and fecundity, (B) transparent, acrylic platform used to support the leaf the bird cherry-oat aphid was reared on, and (C) close up of the adult bird cherry-oat aphid. and the shed exuvia were removed. When the aphid reached adulthood, its fecundity was assessed by counting and removing the progeny every $24 \mathrm{~h}$ for at least 12 days. To evaluate the bird cherry-oat aphid performance, we calculated duration of the period from birth to the onset of both adulthood (development time) and reproduction $(d)$, the mean nymph number per female

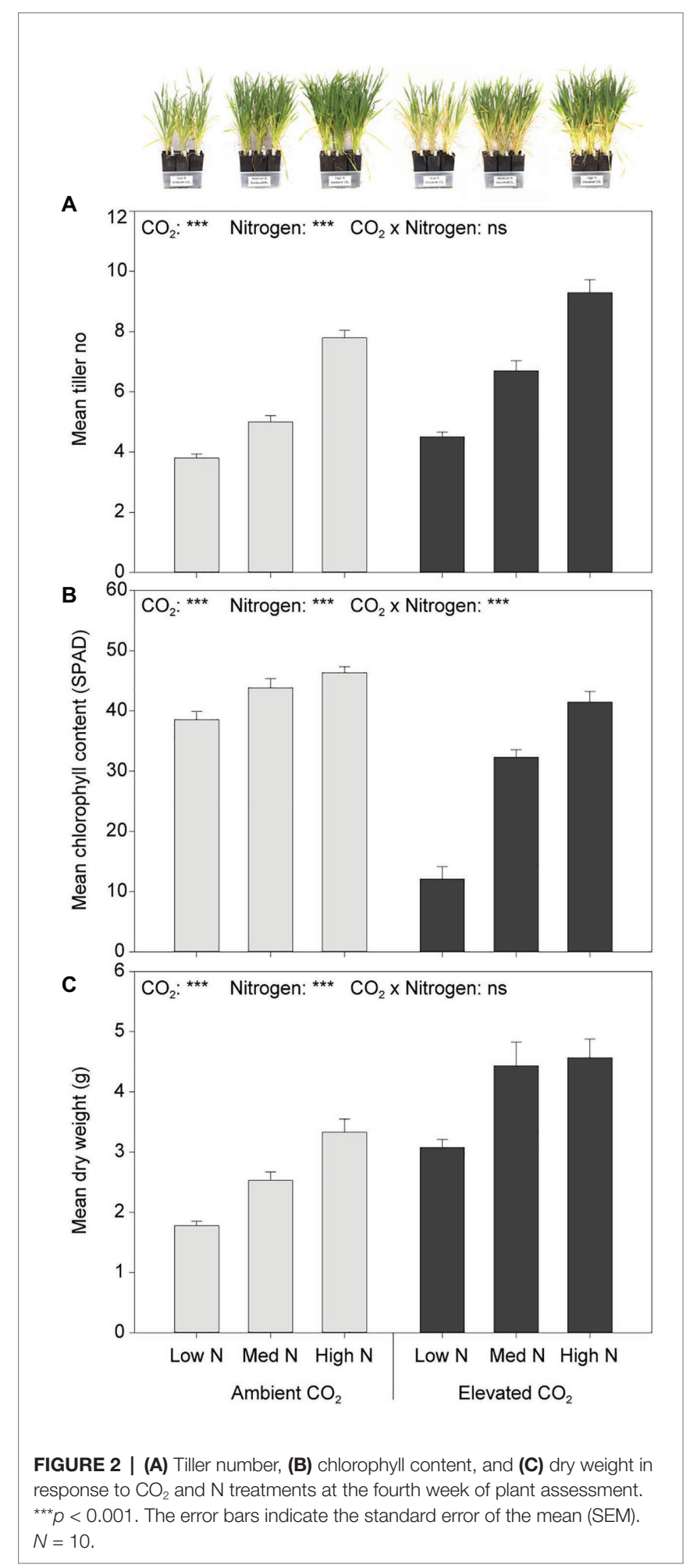


over a period of time equivalent to the pre-reproductive period $\left(M_{\mathrm{d}}\right)$, and the mean number of nymphs produced per aphid female over a 10-day period $\left(M_{10}\right)$. Additionally, we calculated the mean generation time $\left(T_{\mathrm{d}}=\mathrm{d} / 0.738\right)$, the intrinsic rate of natural increase $\left[r_{\mathrm{m}}=0.738\left(\ln M_{\mathrm{d}}\right) / \mathrm{d}\right]$, and the mean relative growth rate $\left(\mathrm{RGR}=r_{\mathrm{m}} / 0.86\right)$ following calculations described by Wyatt and White (1977) and commonly used to assess aphid performance (Dáder et al., 2016; Trębicki et al., 2016; Moreno-Delafuente et al., 2020).

\section{Plant Carbon and Nitrogen Content}

To determine aboveground nitrogen $(\mathrm{N})$ and carbon $(\mathrm{C})$ content, plants were oven dried (TD-150F, Thermoline Scientific, NSW, Australia) at $60^{\circ} \mathrm{C}$ for $72 \mathrm{~h}$, and then finely ground $(<0.5 \mathrm{~mm})$ using a tissue lyser (Retsch MM300, Haan, Germany) prior to analysis by the Dumas combustion method at the University of Melbourne TrACEES Soil Node platform.

\section{Statistical Analysis}

Two-way ANOVA was used to examine the effects of $\mathrm{CO}_{2}, \mathrm{~N}$ and their interaction on wheat growth and quality and aphid development and performance variables. $\mathrm{CO}_{2}$ factor had two levels $\left(\mathrm{aCO}_{2}\right.$ and $\left.\mathrm{eCO}_{2}\right)$ and $\mathrm{N}$ factor had three (low, medium, and high). In the case of a significant interaction of these factors $(p<0.05)$ on any of the measured variables, a simple main effects analysis was conducted. IBM SPSS for Mac was used to perform these analyses (IBM SPSS Statistics for Mac, Chicago, United States).

\section{RESULTS}

\section{Plant $\mathrm{CO}_{2}$ and Nitrogen Response}

At the fourth week of plant assessment, $\mathrm{eCO}_{2}$ significantly increased tiller number by $23 \%\left(F_{1,54}=34.308, p<0.001\right)$ and biomass by $58 \%\left(F_{1,54}=57.401, p<0.001\right)$ when compared to $\mathrm{aCO}_{2}$.

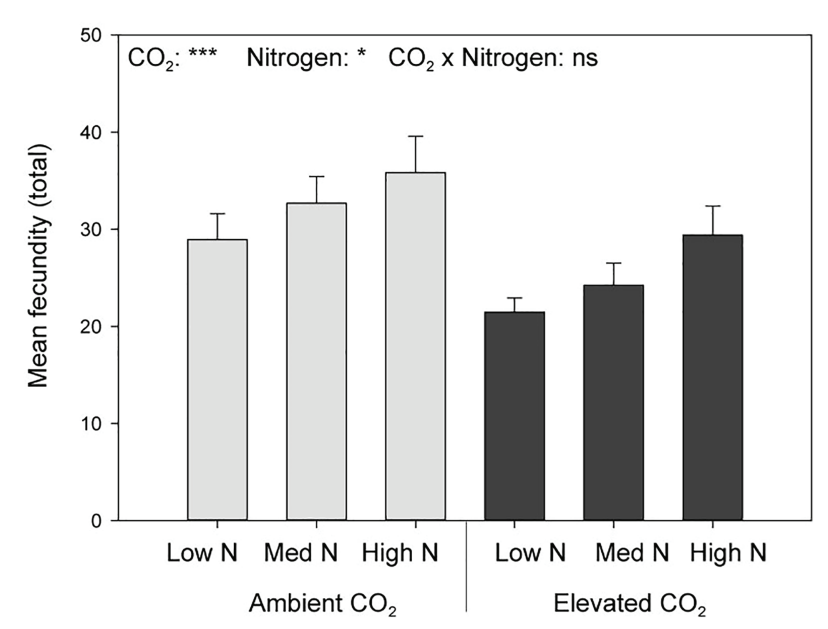

FIGURE 3 | Total fecundity per female aphid in response to $\mathrm{CO}_{2}$ and $\mathrm{N}$ application. ${ }^{*} p<0.05$ and ${ }^{\star \star \star} p<0.001$. The error bars indicate the SEM. $N=14$.
Greater nitrogen application rates also significantly increased tiller number $\left(F_{2,54}=133.263, p<0.001\right.$; Figure 2A). Although the main effect of $\mathrm{N}$ was significant on dry weight $\left(F_{2,54}=21.214\right.$, $p<0.001$ ), plant biomass did not significantly increase between the high and medium $\mathrm{N}$ levels ( $p=0.170$; Figure 2C). Furthermore, the leaf chlorophyll content was significantly decreased by $33 \%$ under $\mathrm{eCO}_{2}$ when compared to $\mathrm{aCO}_{2}\left(F_{1,54}=129.603, p<0.001\right)$, and significantly increased with greater nitrogen application rates $\left(F_{2,54}=76.915, p<0.001\right)$. There was an interaction effect of $\mathrm{CO}_{2}$ and $\mathrm{N}$ on leaf chlorophyll content $\left(F_{2,54}=25.852, p<0.001\right)$.
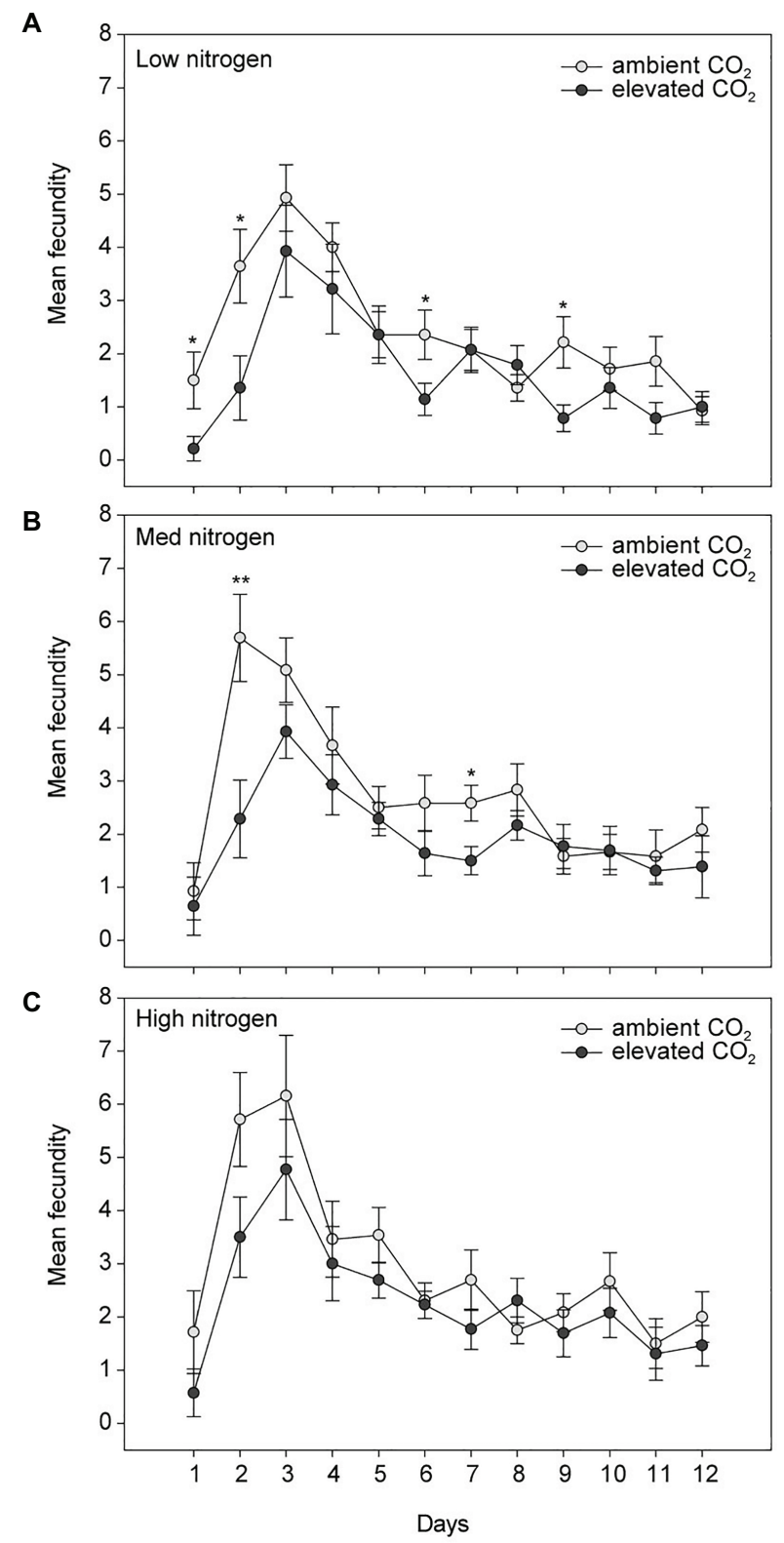

FIGURE 4 | Daily fecundity in response to $\mathrm{CO}_{2}$ and (A) low, (B) medium, and (C) high $\mathrm{N}$ treatments. Day 1 indicates the day the aphid reaches adulthood. ${ }^{*} p<0.05$ and ${ }^{* *} p<0.01$. The error bars indicate the SEM. $N=14$. 
The effect of $\mathrm{N}$ on leaf chlorophyll content was dependent on $\mathrm{CO}_{2}$ condition (Figure 2B). Under $\mathrm{eCO}_{2}$, greater nitrogen application rates significantly increased leaf chlorophyll content $(p<0.001)$. Nevertheless, under $\mathrm{aCO}_{2}$, the leaf chlorophyll content did not significantly differ between the high and the medium $\mathrm{N}$ levels $(p=0.747,95 \% \mathrm{CI}$ of the difference $=-2.83$ to 7.89 ) nor between the medium and low $\mathrm{N}$ levels $(p=0.053,95 \% \mathrm{CI}$ of the difference $=-10.67$ to 0.05$)$, whereas it did between the high and low $\mathrm{N}$ levels $(p<0.01,95 \% \mathrm{CI}$ of the difference $=2.48-$ 13.20; Figure 2B).

\section{Bird Cherry-Oat Aphid Development and Performance}

The average development time of the bird cherry-oat aphid, measured as the duration of the period from birth to adulthood, ranged from 6.29 to 6.86 days across all treatments and was not significantly affected by $\mathrm{N}$ application nor $\mathrm{CO}_{2}$ condition. Elevated $\mathrm{CO}_{2}$ significantly increased the duration of the period from birth to the onset of reproduction $\left(d ; \mathrm{aCO}_{2}=7.78\right.$ and $\mathrm{eCO}_{2}=8.317$ days, $\left.F_{1,76}=11.438, p<0.001\right)$ and the mean generation time $\left(T_{\mathrm{d}}\right.$; $\mathrm{aCO}_{2}=10.52$ and $\mathrm{eCO}_{2}=11.27$ days, $\left.F_{1,70}=10.758, p<0.01\right)$. Nevertheless, greater nitrogen application rates did not affect $d$ $\left(F_{2,76}=1.109, p=0.335\right)$ nor $T_{\mathrm{d}}\left(F_{2,70}=1.277, p=0.285\right)$.

Elevated $\mathrm{CO}_{2}$ significantly decreased the bird cherry-oat aphid total fecundity by $22 \%$, calculated as the mean number of nymphs per aphid over a 12-day period starting from adulthood $\left(\mathrm{aCO}_{2}=32.5\right.$ and $\mathrm{eCO}_{2}=25$ nymphs, $F_{1,70}=11.365$, $p<0.001$; Figure 3). It also decreased aphid daily fecundity when compared to $\mathrm{aCO}_{2}$, even if this difference was only significant on several assessment days for the low and medium $\mathrm{N}$ treatments (Figure 4). Greater nitrogen application rates significantly increased the aphid's total fecundity $\left(F_{2,70}=3.806\right.$, $p<0.05$; Figure 3), as well as the aphid daily fecundity (Figure 4). Moreover, $\mathrm{eCO}_{2}$ significantly decreased the mean nymph number per aphid over a period of time equivalent to the pre-reproductive period $\left(M_{\mathrm{d}}\right)$ by $19 \%\left(F_{1,70}=12.919\right.$, $p<0.001$ ), and decreased the number of nymphs produced by each aphid from the onset of reproduction till the end of the assessment $\left(M_{10}\right)$ by $21 \%\left(F_{1,70}=12.444, p<0.001\right.$; Table 1$)$. Greater nitrogen application rates significantly increased $M_{\mathrm{d}}$ $\left(F_{2,70}=3.530, p<0.05\right)$. The intrinsic rate of natural increase $\left(r_{\mathrm{m}}\right)$ and mean relative growth rate (RGR) were also significantly decreased by $13 \%$ under $\mathrm{eCO}_{2}$ when compared to $\mathrm{aCO}_{2}$ $\left(F_{1,70}=18.676, p<0.001 ;\right.$ Table 1).

\section{Plant $\mathbf{N}$ and $\mathbf{C}$ Analysis}

Neither $\mathrm{CO}_{2}$ nor $\mathrm{N}$ had an effect on plant $\mathrm{C}$ content (Figure 5). Elevated $\mathrm{CO}_{2}$ significantly decreased the $\mathrm{N}$ content of aboveground biomass (both leaves and stems) by $39 \%$ $\left(F_{1,54}=168.848, p<0.001\right)$ and increased the C:N ratio by $81 \%\left(F_{1,54}=106.231, p<0.001\right.$; Figure 5). Furthermore, greater $\mathrm{N}$ application rates significantly increased the $\mathrm{N}$ content $\left(F_{2,54}=245.163, p<0.001\right)$ and decreased the C:N ratio of aboveground biomass $\left(F_{2,54}=139.953, p<0.001\right)$.

\section{DISCUSSION}

Under future climate, the nutritional quality of wheat products will decrease. This can potentially be mitigated by increasing or optimizing fertilizer use, which in turn can increase aphid pest numbers thus the damage caused. To our knowledge, this is the first study which investigates the effects of different levels of $\mathrm{CO}_{2}$ and $\mathrm{N}$ fertilizer application on the development and performance of the bird cherry-oat aphid, which is a global pest and vector of viruses in wheat.

In our study, $\mathrm{eCO}_{2}$ significantly increased tiller number and aboveground dry biomass, which is consistent with previous findings (Bloom et al., 2010; Taub, 2010; Trębicki et al., 2016; Walker et al., 2017; Moreno-Delafuente et al., 2020). The observed $\mathrm{eCO}_{2}$-induced reduction in leaf chlorophyll content (a proxy for plant $\mathrm{N}$ content) has also been noted by others (Myers et al., 2014; Ryan et al., 2014; Dáder et al., 2016; Trębicki et al., 2016;

TABLE 1 | The bird cherry-oat aphid development and performance parameters in response to carbon dioxide $\left(\mathrm{CO}_{2}\right)$ and nitrogen $(\mathrm{N})$ treatments (mean $\pm \mathrm{SEM}$, $N=14)$.

\begin{tabular}{|c|c|c|c|c|c|c|c|}
\hline Aphid parameter & $\mathrm{CO}_{2}$ & Low N & Medium N & High $\mathbf{N}$ & $\mathrm{CO}_{2}$ & $\mathbf{N}$ & $\mathrm{CO}_{2} \times \mathrm{N}$ \\
\hline \multirow[t]{2}{*}{$d$} & $\mathrm{aCO}_{2}$ & $7.79 \pm 0.21$ & $7.85 \pm 0.19$ & $7.71 \pm 0.16$ & $0.001^{\star \star \star}$ & 0.335 & 0.500 \\
\hline & $\mathrm{eCO}_{2}$ & $8.57 \pm 0.20$ & $8.29 \pm 0.19$ & $8.08 \pm 0.18$ & & & \\
\hline \multirow[t]{2}{*}{$T_{\mathrm{d}}$} & $\mathrm{aCO}_{2}$ & $10.55 \pm 0.29$ & $10.61 \pm 0.28$ & $10.39 \pm 0.25$ & $0.002^{\star \star}$ & 0.285 & 0.483 \\
\hline & $\mathrm{eCO}_{2}$ & $11.67 \pm 0.29$ & $11.15 \pm 0.27$ & $10.95 \pm 0.26$ & & & \\
\hline \multirow[t]{2}{*}{$M_{\mathrm{d}}$} & $\mathrm{aCO}_{2}$ & $24.57 \pm 1.89$ & $26.25 \pm 1.54$ & $27.75 \pm 2.30$ & $0.001^{\star \star \star}$ & 0.144 & 0.910 \\
\hline & $\mathrm{eCO}_{2}$ & $19.77 \pm 1.35$ & $20.38 \pm 1.41$ & $23.33 \pm 1.59$ & & & \\
\hline \multirow[t]{2}{*}{$M_{10}$} & $\mathrm{aCO}_{2}$ & $27.57 \pm 2.43$ & $30.17 \pm 2.23$ & $27.42 \pm 2.30$ & $0.001^{\star \star \star}$ & $0.035^{\star}$ & 0.942 \\
\hline & $\mathrm{eCO}_{2}$ & $21.15 \pm 1.44$ & $22.85 \pm 1.80$ & $33.17 \pm 3.05$ & & & \\
\hline \multirow[t]{2}{*}{$r_{\mathrm{m}}$} & $\mathrm{aCO}_{2}$ & $0.31 \pm 0.01$ & $0.31 \pm 0.01$ & $0.32 \pm 0.01$ & $0.000^{\star \star \star}$ & 0.079 & 0.820 \\
\hline & $\mathrm{eCO}_{2}$ & $0.26 \pm 0.01$ & $0.27 \pm 0.01$ & $0.29 \pm 0.01$ & & & \\
\hline \multirow[t]{2}{*}{ RGR } & $\mathrm{aCO}_{2}$ & $0.36 \pm 0.01$ & $0.36 \pm 0.01$ & $0.38 \pm 0.01$ & $0.000^{\star \star \star}$ & 0.079 & 0.820 \\
\hline & $\mathrm{eCO}_{2}$ & $0.30 \pm 0.01$ & $0.32 \pm 0.01$ & $0.34 \pm 0.01$ & & & \\
\hline
\end{tabular}

$d$ is the duration in days of the period from birth to the onset of reproduction, $T_{d}$ is the mean generation time, $M_{d}$ is the mean nymph number per female over a period of time equivalent to the pre-reproductive period, $M_{10}$ is the mean number of nymphs produced per aphid female over a 10-day period, $r_{m}$ is the intrinsic rate of natural increase, and RGR is the mean relative growth rate. ${ }^{*} p<0.05 ;{ }^{* *} p<0.01 ;{ }^{* * *} p<0.001$. 


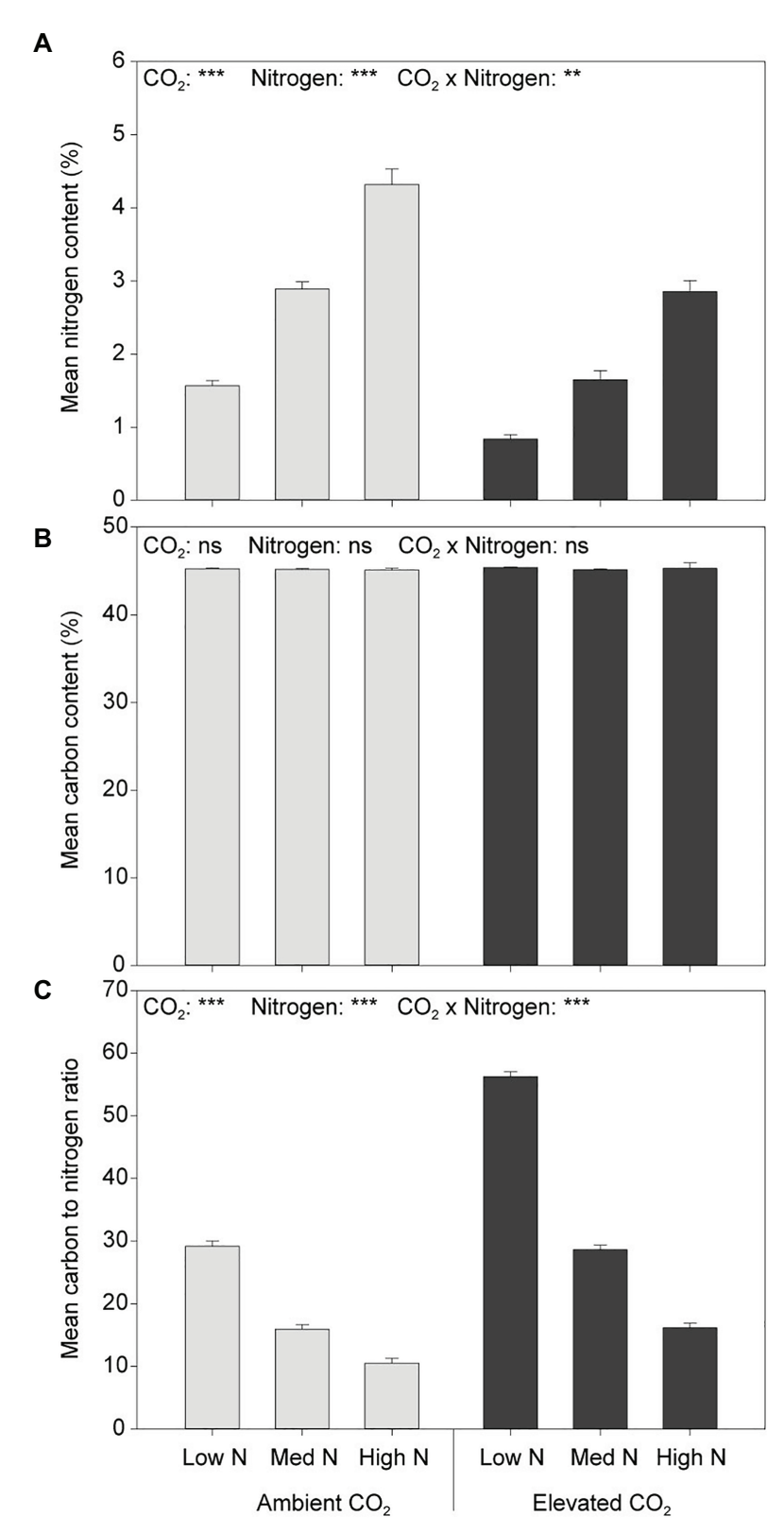

FIGURE 5 | (A) $\mathrm{N}$ content, (B) $\mathrm{C}$ content, and (C) $\mathrm{C}: \mathrm{N}$ in response to $\mathrm{CO}_{2}$ and $\mathrm{N}$ treatments. ${ }^{\star \star *} p<0.001$. The error bars indicate the SEM. $N=10$.

Vassiliadis et al., 2018; Moreno-Delafuente et al., 2020). The mechanisms responsible for such a reduction are not fully understood, though Myers et al. (2014) proposed that it may be due to a combination of factors including carbohydrate dilution, slower $\mathrm{N}$ uptake in the roots and decreased transpiration-driven $\mathrm{N}$ flow, among others. It has also been suggested that nitrate assimilation is suppressed under $\mathrm{eCO}_{2}$ (Bloom et al., 2010).

Nitrogen fertilizer application often improves wheat yield (Sudderth et al., 2005; Belete et al., 2018; Xu et al., 2020). We observed that greater $\mathrm{N}$ application rates significantly increased tiller number, aboveground dry biomass, leaf chlorophyll content and plant $\mathrm{N}$ content of wheat, in agreement with different studies on wheat and other plant species (Chaturvedi, 2005; Sudderth et al., 2005; Walker et al., 2017). In our study, the positive effect of $\mathrm{N}$ fertilization on wheat $\mathrm{N}$ content was not sufficient to compensate for its reduction induced by $\mathrm{eCO}_{2}$. This suggests that the addition of $\mathrm{N}$ alone may not be able to sustain wheat $\mathrm{N}$ content under future $\mathrm{CO}_{2}$ conditions. Indeed, $\mathrm{N}$ application was not able to revert the $\mathrm{eCO}_{2}$-induced reduction in wheat grain protein concentration even under high $\mathrm{N}$ input (Walker et al., 2017).

Nitrogen is also an important macronutrient for aphid biological functions (Mattson, 1980). We found that the parameters used to evaluate aphid performance $\left(M_{\mathrm{d}}, M_{10}, r_{\mathrm{m}}\right.$, and RGR) were increased as the plant $\mathrm{N}$ content of the leaf tissue increased. Nevertheless, another study reported that the effect of $\mathrm{eCO}_{2}$ and high $\mathrm{N}$ inputs on Solanum dulcamara and Amaranthus viridis aphid populations was not dependent on the leaf $\mathrm{C}: \mathrm{N}$ ratio (Sudderth et al., 2005). This supports that different insectplant models respond differently to $\mathrm{eCO}_{2}$ (Ryalls and Harrington, 2016). Several studies have reported an increase in aphid fecundity (Jiang et al., 2018) and abundance (Ryan et al., 2015), while others a decrease in aphid fecundity under $\mathrm{eCO}_{2}$ (Newman et al., 1999; Awmack et al., 2004; Oehme et al., 2013; Ryan et al., 2014; Dáder et al., 2016; Trębicki et al., 2016; Moreno-Delafuente et al., 2020). Although we found that $\mathrm{eCO}_{2}$ significantly decreased the fecundity of the bird cherry-oat aphid, it was overall lower than that reported by Trębicki et al. (2016) on the same insectplant model and under similar conditions (controlled plant growth chambers set at $20^{\circ} \mathrm{C} ; \mathrm{aCO}_{2}=385 \mathrm{ppm}$ and $\mathrm{eCO}_{2}=650 \mathrm{ppm}$ ). Thus, the decrease in aphid fecundity under $\mathrm{eCO}_{2}$ could be attributed to the decrease in tissue $\mathrm{N}$ content, as well as to changes in the amino acid content in the phloem (Oehme et al., 2013; Ryalls and Harrington, 2016). We suspect that the lower fecundity under both $\mathrm{aCO}_{2}$ and $\mathrm{eCO}_{2}$ observed in our study when compared to that of Trębicki et al. (2016) may be caused by the rapid depletion of $\mathrm{N}$ by the wheat plants supplied with a single $\mathrm{N}$ application at sowing. Future studies would benefit from investigating the interactive effects of $\mathrm{eCO}_{2}$ and $\mathrm{N}$ application at different plant growth stages for different insect-plant models.

Furthermore, we found that $\mathrm{eCO}_{2}$ did not have a significant effect on aphid development time, measured as the duration of the period from birth to adulthood. This is consistent with a study using the same insect-plant model Trębicki et al. (2016), as well as others on different aphids and their predators (Awmack et al., 2004; Boullis et al., 2018; Jiang et al., 2018). However, a decrease in aphid development time was observed under $\mathrm{eCO}_{2}$ in Brevicoryne brassicae when reared on ornamental cabbages (Amiri-Jami et al., 2012). We found that greater $\mathrm{N}$ application rates did not significantly affect aphid development, duration of the period from birth to the onset of reproduction or mean generation time. Although the importance of $\mathrm{N}$ in aphid biological functions is widely reported (Hosseini et al., 2010; Zarghami et al., 2010), our study suggests that aphid development was not affected by $\mathrm{N}$ content or was potentially dulled by a stronger $\mathrm{eCO}_{2}$ effect.

We investigated the impact of $\mathrm{CO}_{2}$ levels, $\mathrm{N}$ application rates and their interactions on wheat growth and $\mathrm{N}$ content, 
and the development and performance of the bird cherry-oat aphid. Our study provides insights into aphid and wheat interactions under predicted future, higher $\mathrm{CO}_{2}$ climate, where management options to revert the $\mathrm{CO}_{2}$-induced reduction in grain protein content might be considered. It highlights the importance of considering the flow-on effects on insect pests when assessing strategies to address nutrient deficiency in cereals.

\section{DATA AVAILABILITY STATEMENT}

The raw data supporting the conclusions of this article will be made available by the authors, without undue reservation.

\section{REFERENCES}

Amiri-Jami, A. R., Sadeghi, H., and Shoor, M. (2012). The performance of Brevicoryne brassicae on ornamental cabbages grown in $\mathrm{CO}_{2}$-enriched atmospheres. J. Asia Pac. Entomol. 15, 249-253. doi: 10.1016/j.aspen.2012.01.001

Aqueel, M., and Leather, S. (2011). Effect of nitrogen fertilizer on the growth and survival of Rhopalosiphum padi (L.) and Sitobion avenae (F.) (Homoptera: Aphididae) on different wheat cultivars. Crop Prot. 30, 216-221. doi: 10.1016/j. cropro.2010.09.013

Awika, J. M., Piironen, V., and Bean, S. (2011). Advances in cereal science: Implications to food processing and health promotion. Washington, USA: ACS Publications.

Awmack, C. S., Harrington, R., and Lindroth, R. L. (2004). Aphid individual performance may not predict population responses to elevated $\mathrm{CO}_{2}$ or $\mathrm{O}_{3}$. Glob. Chang. Biol. 10, 1414-1423. doi: 10.1111/j.1365-2486.2004.00800.x

Belete, F., Dechassa, N., Molla, A., and Tana, T. (2018). Effect of nitrogen fertilizer rates on grain yield and nitrogen uptake and use efficiency of bread wheat (Triticum aestivum L.) varieties on the Vertisols of central highlands of Ethiopia. Agric. Food Secur. 7, 1-12. doi: 10.1186/s40066-018-0231-z

Bloom, A. J., Burger, M., Asensio, J. S. R., and Cousins, A. B. (2010). Carbon dioxide enrichment inhibits nitrate assimilation in wheat and Arabidopsis. Science 328, 899-903. doi: 10.1126/science.1186440

Boe, A., and Beck, D. L. (2008). Yield components of biomass in switchgrass. Crop Sci. 48, 1306-1311. doi: 10.2135/cropsci2007.08.0482

Boullis, A., Francis, F., and Verheggen, F. (2018). Aphid-hoverfly interactions under elevated $\mathrm{CO}_{2}$ concentrations: oviposition and larval development. Physiol. Entomol. 43, 245-250. doi: 10.1111/phen.12253

Campbell, B. M., Vermeulen, S. J., Aggarwal, P. K., Corner-Dolloff, C., Girvetz, E., Loboguerrero, A. M., et al. (2016). Reducing risks to food security from climate change. Glob. Food Sec. 11, 34-43. doi: 10.1016/j.gfs.2016.06.002

Chaturvedi, I. (2005). Effect of nitrogen fertilizers on growth, yield and quality of hybrid rice (Oryza sativa). J. Cent. Eur. Agric. 6, 611-618.

Cisneros, J. J., and Godfrey, L. D. (2001). Midseason pest status of the cotton aphid (Homoptera: Aphididae) in California cotton-is nitrogen a key factor? Environ. Entomol. 30, 501-510. doi: 10.1603/0046-225X-30.3.501

Dáder, B., Fereres, A., Moreno, A., and Trębicki, P. (2016). Elevated $\mathrm{CO}_{2}$ impacts bell pepper growth with consequences to Myzus persicae life history, feeding behaviour and virus transmission ability. Sci. Rep. 6:19120. doi: 10.1038/srep19120

Demir, N., Sönmez, N. K., Akar, T., and Ünal, S. (2018). "Automated measurement of plant height of wheat genotypes using a DSM derived from UAV imagery" in Multidisciplinary Digital Publishing Institute Proceedings. 350.

Deutsch, C. A., Tewksbury, J. J., Tigchelaar, M., Battisti, D. S., Merrill, S. C., Huey, R. B., et al. (2018). Increase in crop losses to insect pests in a warming climate. Science 361, 916-919. doi: 10.1126/science.aat3466

Fitzgerald, G. J., Tausz, M., O’leary, G., Mollah, M. R., Tausz-Posch, S., Seneweera, S., et al. (2016). Elevated atmospheric $\left[\mathrm{CO}_{2}\right]$ can dramatically increase wheat yields in semi-arid environments and buffer against heat waves. Glob. Chang. Biol. 22, 2269-2284. doi: 10.1111/gcb.13263

García-Lara, S., and Saldivar, S. S. (2016). "Insect pests" in Encyclopedia of food and health. (Elsevier), 432-436.

\section{AUTHOR CONTRIBUTIONS}

EC, SL, and PT planned and designed the research. EC and PT performed experiments and analyzed the data. EC wrote the manuscript, and SL and PT revised it. All authors contributed to the article and approved the submitted version.

\section{ACKNOWLEDGMENTS}

We would like to thank Agriculture Victoria and The University of Melbourne for their support, as well as Narelle Nancarrow, Mohammad Aftab, Solomon Maina, and Ana Moreno for their assistance.

Gash, A. F. (2012). Wheat nitrogen fertilisation effects on the performance of the cereal aphid Metopolophium dirhodum. Agronomy 2, 1-13. doi: 10.3390/ agronomy2010001

Högy, P., Wieser, H., Köhler, P., Schwadorf, K., Breuer, J., Franzaring, J., et al. (2009). Effects of elevated $\mathrm{CO}_{2}$ on grain yield and quality of wheat: results from a 3-year free-air $\mathrm{CO}_{2}$ enrichment experiment. Plant Biol. 11, 60-69. doi: 10.1111/j.1438-8677.2009.00230.x

Hosseini, M., Ashouri, A., Enkegaard, A., Goldansaz, S. H., Nassiri Mahalati, M., and Hosseininaveh, V. (2010). Performance and population growth rate of the cotton aphid, and associated yield losses in cucumber, under different nitrogen fertilization regimes. Int. J. Pest Manag. 56, 127-135. doi: 10.1080/ 09670870903248827

Hughes, L., and Bazzaz, F. A. (2001). Effects of elevated $\mathrm{CO}_{2}$ on five plant-aphid interactions. Entomol. Exp. Appl. 99, 87-96. doi: 10.1046/j.1570-7458.2001.00805.x

IPCC (2012). Changes in climate extremes and their impacts on the natural physical environment. Managing the risks of extreme events and distasters to advance climate change adaptation.

IPCC (2014). Climate Change 2014 Synthesis Report: summary for policymakers.

Jablonski, L. M., Wang, X., and Curtis, P. S. (2002). Plant reproduction under elevated $\mathrm{CO}_{2}$ conditions: a meta-analysis of reports on 79 crop and wild species. New Phytol. 156, 9-26. doi: 10.1046/j.1469-8137.2002.00494.x

Jahn, G. C., Almazan, L. P., and Pacia, J. B. (2005). Effect of nitrogen fertilizer on the intrinsic rate of increase of Hysteroneura setariae (Thomas) (Homoptera: Aphididae) on rice (Oryza sativa L.). Environ. Entomol. 34, 938-943. doi: 10.1603/0046-225X-34.4.938

Jiang, S., Dai, Y., Lu, Y., Fan, S., Liu, Y., Bodlah, M. A., et al. (2018). Molecular evidence for the fitness of cotton aphid, Aphis gossypii in response to elevated $\mathrm{CO}_{2}$ from the perspective of feeding behavior analysis. Front. Physiol. 9:1444. doi: $10.3389 /$ fphys.2018.01444

Johnson, S. N., and Jones, T. H. (2017). Global climate change and terrestrial invertebrates. Chichester, UK: John Wiley \& Sons.

Johnson, S. N., and Züst, T. (2018). Climate change and insect pests: resistance is not futile? Trends Plant Sci. 23, 367-369. doi: 10.1016/j.tplants.2018.03.001

Jones, R. A., and Naidu, R. A. (2019). Global dimensions of plant virus diseases: current status and future perspectives. Ann. Rev. Virol. 6, 387-409. doi: 10.1146/annurev-virology-092818-015606

Khan, M., and Port, G. (2008). Performance of clones and morphs of two cereal aphids on wheat plants with high and low nitrogen content. Entomol. Sci. 11, 159-165. doi: 10.1111/j.1479-8298.2008.00262.x

Lam, S. K., Chen, D., Norton, R., Armstrong, R., and Mosier, A. R. (2012). Nitrogen dynamics in grain crop and legume pasture systems under elevated atmospheric carbon dioxide concentration: a meta-analysis. Glob. Chang. Biol. 18, 2853-2859. doi: 10.1111/j.1365-2486.2012.02758.x

Li, F., Dudley, T. L., Chen, B., Chang, X., Liang, L., and Peng, S. (2016). Responses of tree and insect herbivores to elevated nitrogen inputs: a metaanalysis. Acta Oecol. 77, 160-167. doi: 10.1016/j.actao.2016.10.008

Luck, J., Spackman, M., Freeman, A., Trębicki, P., Griffiths, W., Finlay, K., et al. (2011). Climate change and diseases of food crops. Plant Pathol. 60, 113-121. doi: 10.1111/j.1365-3059.2010.02414.x 
Mattson, W. J. (1980). Herbivory in relation to plant nitrogen content. Annu. Rev. Ecol. Syst. 11, 119-161. doi: 10.1146/annurev.es.11.110180.001003

Mbow, C., and Rosenzweig, C. (2019). Chapter 5: food security. Climate change and land: an IPCC special report on climate change, desertification, land degradation, sustainable land management, food security, and greenhouse gas fluxes in terrestrial ecosystems.

Mitchell, R. A. C., Mitchell, V. J., Driscoll, S. P., Franklin, J., and Lawlor, D. W. (1993). Effects of increased $\mathrm{CO}_{2}$ concentration and temperature on growth and yield of winter wheat at two levels of nitrogen application. Plant Cell Environ. 16, 521-529. doi: 10.1111/j.1365-3040.1993.tb00899.x

Morales-Hojas, R., Gonzalez-Uriarte, A., Alvira Iraizoz, F., Jenkins, T., Alderson, L., Kruger, T., et al. (2020). Population genetic structure and predominance of cyclical parthenogenesis in the bird cherry-oat aphid Rhopalosiphum padi in England. Evol. Appl. 13, 1009-1025. doi: 10.1111/eva.12917

Moreno-Delafuente, A., Viñuela, E., Fereres, A., Medina, P., and Trębicki, P. (2020). Simultaneous increase in $\mathrm{CO}_{2}$ and temperature alters wheat growth and aphid performance differently depending on virus infection. Insects 11:459. doi: 10.3390/insects11080459

Myers, S. S., Zanobetti, A., Kloog, I., Huybers, P., Leakey, A. D. B., Bloom, A. J., et al. (2014). Increasing $\mathrm{CO}_{2}$ threatens human nutrition. Nature 510, 139-142. doi: $10.1038 /$ nature 13179

Newman, J., Gibson, D., Hickam, E., Lorenz, M., Adams, E., Bybee, L., et al. (1999). Elevated carbon dioxide results in smaller populations of the bird cherry-oat aphid Rhopalosiphum padi. Ecol. Entomol. 24, 486-489. doi: 10.1046/j.1365-2311.1999.00210.x

NOAA (2020). Trends in atmospheric carbon dioxide [Online]. Available at: www.noaa.gov

Oehme, V., Högy, P., Zebitz, C. P. W., and Fangmeier, A. (2013). Effects of elevated atmospheric $\mathrm{CO}_{2}$ concentrations on phloem sap composition of spring crops and aphid performance. J. Plant Interact. 8, 74-84. doi: $10.1080 / 17429145.2012 .736200$

O’Leary, G. J., Christy, B., Nuttall, J., Huth, N., Cammarano, D., Stöckle, C., et al. (2015). Response of wheat growth, grain yield and water use to elevated $\mathrm{CO}_{2}$ under a free-air $\mathrm{CO}_{2}$ enrichment (FACE) experiment and modelling in a semi-arid environment. Glob. Chang. Biol. 21, 2670-2686. doi: $10.1111 /$ gcb. 12830

Robinson, E. A., Ryan, G. D., and Newman, J. A. (2012). A meta-analytical review of the effects of elevated $\mathrm{CO}_{2}$ on plant-arthropod interactions highlights the importance of interacting environmental and biological variables. New Phytol. 194, 321-336. doi: 10.1111/j.1469-8137.2012.04074.x

Ryalls, J. M., and Harrington, R. (2016). "Climate and atmospheric change impacts on aphids as vectors of plant diseases" in Global climate change and terrestrial invertebrates. eds. S. N. Johnson and T. H. Jones (UK: John Wiley \& Sons), 148-175.

Ryan, G. D., Shukla, K., Rasmussen, S., Shelp, B. J., and Newman, J. A. (2014). Phloem phytochemistry and aphid responses to elevated $\mathrm{CO}_{2}$, nitrogen fertilization and endophyte infection. Agric. For. Entomol. 16, 273-283. doi: 10.1111/afe. 12055

Ryan, G. D., Sylvester, E. V. A., Shelp, B. J., and Newman, J. A. (2015). Towards an understanding of how phloem amino acid composition shapes elevated $\mathrm{CO}_{2}$-induced changes in aphid population dynamics. Ecol. Entomol. 40, 247-257. doi: 10.1111/een.12181

Shewry, P. R., and Hey, S. J. (2015). The contribution of wheat to human diet and health. Food Energy Secur. 4, 178-202. doi: 10.1002/fes3.64

Smith, P., and Sward, R. (1982). Crop loss assessment studies on the effects of Barley yellow dwarf virus in wheat in Victoria. Aust. J. Agric. Res. 33, 179-185. doi: 10.1071/AR9820179

Speight, J. G. (2017). "Chapter three-industrial inorganic chemistry" in Environmental inorganic chemistry for engineers. 1st Edn. (ButterworthHeinemann: Wyoming, United States), 111-169.

Stocker, T. F., Qin, D., Plattner, G. -K., Tignor, M., Allen, S. K., Boschung, J., et al. (2013). Climate change 2013: the physical science basis. Contribution of working group I to the fifth assessment report of the intergovernmental panel on climate change. 1535
Sudderth, E. A., Stinson, K. A., and Bazzaz, F. A. (2005). Host-specific aphid population responses to elevated $\mathrm{CO}_{2}$ and increased $\mathrm{N}$ availability. Glob. Chang. Biol. 11, 1997-2008. doi: 10.1111/j.1365-2486.2005.01006.x

Taub, D. (2010). Effects of rising atmospheric concentrations of carbon dioxide on plants. Nat. Educ. Knowl. 3:21.

Taub, D., Miller, B., and Allen, H. (2008). Effects of elevated $\mathrm{CO}_{2}$ on the protein concentration of food crops: a meta-analysis. Glob. Chang. Biol. 14, 565-575. doi: 10.1111/j.1365-2486.2007.01511.x

Trębicki, P. (2020). Climate change and plant virus epidemiology. Virus Res. 286:198059. doi: 10.1016/j.virusres.2020.198059

Trębicki, P., and Finlay, K. (2019). "Pests and diseases under climate change; its threat to food security" in Food security and climate change. eds. S. S. Yadav, R. J. Redden, J. L. Hatfield, A. W. Ebert and D. Hunter, 229-249.

Trębicki, P., Nancarrow, N., Bosque-Pérez, N. A., Rodoni, B., Aftab, M., Freeman, A., et al. (2017). Virus incidence in wheat increases under elevated $\mathrm{CO}_{2}$ : a 4-year study of yellow dwarf viruses from a free-air carbon dioxide facility. Virus Res. 241, 137-144. doi: 10.1016/j.virusres.2017.06.027

Trębicki, P., Vandegeer, R. K., Bosque-Pérez, N. A., Powell, K. S., Dáder, B., Freeman, A. J., et al. (2016). Virus infection mediates the effects of elevated $\mathrm{CO}_{2}$ on plants and vectors. Sci. Rep. 6:22785. doi: $10.1038 / \operatorname{srep} 22785$

United Nations (2019). 9.7 billion on Earth by 2050, but growth rate slowing, says new UN population report [Online].

Vassiliadis, S., Plummer, K. M., Powell, K. S., and Rochfort, S. J. (2018). Elevated $\mathrm{CO}_{2}$ and virus infection impacts wheat and aphid metabolism. Metabolomics 14:133. doi: 10.1007/s11306-018-1425-x

Vassiliadis, S., Plummer, K. M., Powell, K. S., Trębicki, P., Luck, J. E., and Rochfort, S. J. (2016). The effect of elevated $\mathrm{CO}_{2}$ and virus infection on the primary metabolism of wheat. Funct. Plant Biol. 43, 892-902. doi: 10.1071/FP15242

Walker, C., Armstrong, R., Panozzo, J., Partington, D., and Fitzgerald, G. (2017). Can nitrogen fertiliser maintain wheat (Triticum aestivum) grain protein concentration in an elevated $\mathrm{CO}_{2}$ environment? Soil Res. 55, 518-523. doi: 10.1071/SR17049

Wang, L., Feng, Z., and Schjoerring, J. K. (2013). Effects of elevated atmospheric $\mathrm{CO}_{2}$ on physiology and yield of wheat (Triticum aestivum L.): a metaanalytic test of current hypotheses. Agric. Ecosyst. Environ. 178, 57-63. doi: 10.1016/j.agee.2013.06.013

Wyatt, I., and White, P. (1977). Simple estimation of intrinsic increase rates for aphids and tetranychid mites. J. Appl. Ecol. 14, 757-766. doi: 10.2307/2402807

Xing, G., Zhang, J., Liu, J., Zhang, X., Wang, G., and Wang, Y. (2003). Impacts of atmospheric $\mathrm{CO}_{2}$ concentrations and soil water on the population dynamics, fecundity and development of the bird cherry-oat aphid Rhopalosiphum padi. Phytoparasitica 31, 499-514. doi: 10.1007/BF02979743

Xiong, D., Chen, J., Yu, T., Gao, W., Ling, X., Li, Y., et al. (2015). SPAD-based leaf nitrogen estimation is impacted by environmental factors and crop leaf characteristics. Sci. Rep. 5:13389. doi: 10.1038/srep13389

Xu, A., Li, L., Xie, J., Wang, X., Coulter, J. A., Liu, C., et al. (2020). Effect of long-term nitrogen addition on wheat yield, nitrogen use efficiency, and residual soil nitrate in a semiarid area of the loess plateau of China. Sustainability 12:1735. doi: 10.3390/su12051735

Zarghami, S., Allahyari, H., Bagheri, M. R., and Saboori, A. (2010). Effect of nitrogen fertilization on life table parameters and population growth of Brevicoryne brassicae. Bull. Insectol. 63, 39-43.

Conflict of Interest: The authors declare that the research was conducted in the absence of any commercial or financial relationships that could be construed as a potential conflict of interest.

Copyright (c) 2020 Carreras Navarro, Lam and Trębicki. This is an open-access article distributed under the terms of the Creative Commons Attribution License (CC BY). The use, distribution or reproduction in other forums is permitted, provided the original author(s) and the copyright owner(s) are credited and that the original publication in this journal is cited, in accordance with accepted academic practice. No use, distribution or reproduction is permitted which does not comply with these terms. 